based publication Disarmament Intelligence Review, believes there has to be some explanation for high levels of enriched uranium around Greenham Common in the 1950s. An accident or fire appears the most likely cause as nuclear weapons were deployed but not manufactured at Greenham Common, she says.

Both Johnson and Norris say the British government should be less secretive about nuclear accidents, in line with the US decision to do so in the early 1980s. "Local residents and the emergency services need to be fully briefed," says Johnson. But such a move is unlikely to be supported within the $\mathrm{MoD}$ on national security grounds.

Sir Hermann Bondi, chief scientific adviser to the MoD between 1971 and 1977 suggests that the 'public interest' is not always served best by total transparency. "It is not in the public interest that many people should know the location of a [nuclear weapon] store, or what is in it."

But Johnson says 'politics' rather than national security is the reason why accidents at Britain's nuclear installations remain a secret. The government, she says, was determined to push ahead with deploying nuclear weapons in Britain. But it was under pressure from the newly formed Campaign for Nuclear Disarmament (CND). Any adverse publicity from nuclear accidents would have made the CND's case much stronger, she says.

Ehsan Masood

\title{
Panel proposes disarmament guide
}

Sydney. A report from a high-level international panel of scientists, politicians and diplomats last week not only concluded that the time has come to eliminate nuclear weapons, but proposed a detailed scheme to achieve this.

The 17 members of the Canberra Commission on the Elimination of Nuclear Weapons including Robert McNamara, a former US defence secretary, Michel Rocard, a former French Socialist prime minister, and Joseph Rotblat, president of Pugwash and the 1995 winner of the Nobel peace prize. The leading academic on the panel is Robert O'Neill, an Australian national and now Oxford professor of the history of war. The panel's findings will be presented to the general assembly of the United Nations next month.

The panel calls for "immediate and determined efforts [to] rid the world of nuclear weapons and the threat they pose to it", while warning of "the increasing odds of a calamity" despite the end of the Cold War. It urges the five nuclear weapons states - the United States, Russia, France, China and the United Kingdom - to "commit themselves unequivocally to the elimination of nuclear weapons and to agree to start work immediately on the practical steps and negotiations required for its achievement".
O'Neill describes the panel's recommendations as "the fullest and most radical yet". They include six steps towards disarmament: taking nuclear forces off alert, removing warheads, ending deployment of non-strategic nuclear weapons, banning nuclear tests, further reducing US and Russian nuclear arsenals, and agreement on a "no first use" policy. The group deliberately refrained from setting a timetable for these steps.

The commission says its proposals are realistic, and its report includes 300 pages of technical analysis - of the thorny issue of verification in particular - to support this claim. Whether the report's recommendations will have any practical effect will depend much on mobilising public opinion in the United States after November's presidential election, according to O'Neill.

"The reaction of the US State Department has been good and sympathetic," he says. "They could have chucked it in the bin."

Peter Pockley

\section{Correction}

Joseph A. Burns of Cornell University was chairman of the Committee on Planetary and Lunar Exploration (COMPLEX) when its report on Mars missions was being written, and not Ron Greeley, who is the current chairman (see Nature 382, 481; 1996).
Does your automated DNA sequencer leave you guessing? If so, chances are it's primarily designed for high throughput sequencing. Why be uncertain of your sequencer's accuracy, when ALFexpress ${ }^{\text {Tw }}$ is providing researchers with the full genetic stories of their DNA.

\section{ATT Pxgress: for more accurate readings}

In the largest clinical study using automated DNA sequencing, the technology behind ALFexpress proved exceptional (see caption). That's one of many examples of ALFexpress offering unrivaled accuracy during automated confirmatory sequencing. Further, its readings are so accurate that ALFexpress can unambiguously identify heterozygous point mutations-as proven in many clinical research applications, such as analysis of tumor genes and high-resolution HLA typing. What's more, Pharmacia Biotech has dedicated software programs to support these applications.

For the full story, call us: I (800) 526-3593 from the U.S.; +8I (0)3 3492 6949 from Japan; or $+46(0) 18165000$ from Europe and the rest of the world. Or visit us on the Internet: http://wnww.biotech.pharmacia.se.

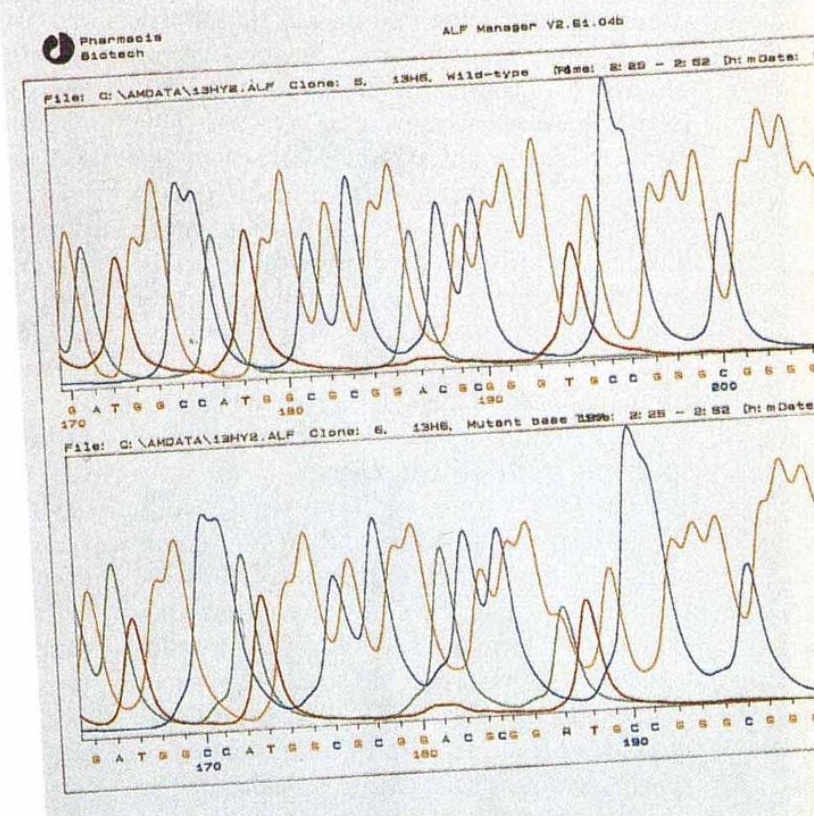

The $p 53$ gene from 316 breast cancer patients was sequenced using ALF automated sequencing technology. (Bergh J., Norberg, T., Sjögren, S., Lindgren A., Holmberg, L. "Complete Sequencing of the $p 53$ Gene ..." Nature Medicine 1995; 10:1029-1034.) 